\title{
UTILITY OF VESTIBULAR EVOKED MYOGENIC POTENTIALS IN THE DIAGNOSIS OF MENIERE'S DISEASE: A REVIEW
}

\section{P. Saravanan, Sujeet Kumar Sinha}

Department of Audiology, All India Institute of Speech and Hearing, Manasagangothri, Mysore-6, India

Corresponding author: Sujeet Kumar Sinha, Department of Audiology, All India Institute of Speech and Hearing, Mysore, Karnataka, India-570006, e-mail: sujitks5@gmail.com, Tel: +91-821-2514449

\begin{abstract}
Meniere's disease is an inner ear disorder characterized by aural fullness, spontaneous attacks of vertigo, fluctuating low-frequency sensorineural hearing loss and tinnitus. There are various tests such as puretone audiometry, electrocochleography, glycerol test, Caloric test, Cochlear hydrops analysis masking which have been utilised in diagnosing the Meniere's disease. Recently cervical vestibular evoked myogenic potentials and ocular vestibular myogenic potentials have been utilised to measure the functioning of the sacculocollic and otolith ocular pathway respectively. The objective of the present study is to provide an overview of the cervical and ocular vestibular evoked myogenic potentials tests findings in individuals with Meniere's disease.
\end{abstract}

Keywords: Meniere's disease • cervical vestibular evoked myogenic potentials • ocular vestibular evoked myogenic potentials

\section{UTILIDAD DE POTENCIALES VESTIBULARES MIOGÉNICOS EVOCADOS (PME)} EN EL DIAGNÓSTICO DE LA ENFERMEDAD DE MENIERE: REVISIÓN

\section{Resumen}

La enfermedad de Meniere (MD) es el trastorno del oído interno; sus síntomas característicos son sensación de plenitud en el oído, episodios repentinos de vértigo, pérdida de la audición neurosensorial variable de la recepción de frecuencia baja y el tinitus.

En el diagnóstico de MD se aplican varias pruebas, tales como audiometría de tonos puros, electrococleografía, test de glicerol, prueba calórica y la prueba CHAMP (procedimiento del análisis del hidrocele coclear con el enmascaramiento). Recientemente se ha empezado a utilizar los estudios de los potenciales vestibulares miogénicos evocados (PVME) cervicales y oculares en personas, para la medición, respectivamente, del reflejo del sáculo-cervical y otolito-oculomotor. El objetivo del presente estudio es la presentación de la revisión de pruebas cervicales y oculares de en personas que padecen MD.

Palabras clave: enfermedad de Meniere • potenciales vestibulares miogénicos evocados (PVME) cervicales • potenciales vestibulares miogénicos evocados (PVME) oculares

\section{ПОЛЕЗНОСТЬ ВЫЗВАННЫХ ВЕСТИБУЛЯРНЫХ МИОГЕННЫХ ПОТЕНЦИАЛОВ В ДИАГНОСТИКЕ БОЛЕЗНИ МЕНЬЕРА: ОБОЗРЕНИЕ}

\section{Изложение}

Болезнь Меньера (MD) - это нарушение внутреннего уха, характеристическими симптомами которого являются ощущение полноты в ухе, спонтанные приступы головокружения, переменная перцептивная тугоухость в пределах низких частот и ушной шум. В диагностике MD используются разные методы исследований, такие как тональная аудиометрия, электрокохлеография, глицериновый тест, калорическая проба и исследование СНАМР (процедура исследования отека улитки с маскировкой). В последнее время начали применять метод вызванных шейных и зрительных вестибулярных миогенных потенциалов для измерения вестибуло-шейного и вестибулоокулярного рефлекса. Цель настоящей работы - представление обозрения тестов вызванных миогенных шейных и зрительных потенциалов у людей с MD.

Ключевые слова: болезнь Меньера • шейные вызванные вестибулярные миогенные потенциалы • зрительные вызванные вестибулярные миогенные потенциалы 


\title{
UŻYTECZNOŚĆ MIOGENNYCH PRZEDSIONKOWYCH POTENCJAŁÓW WYWOŁANYCH W DIAGNOSTYCE CHOROBY MENIERE'A: PRZEGLĄD
}

\begin{abstract}
Streszczenie
Choroba Meniere’a (MD) jest zaburzeniem ucha wewnętrznego, którego charakterystycznymi objawami są uczucie pełności w uchu, spontaniczne napady zawrotów głowy, zmienny niedosłuch odbiorczy w zakresie niskich częstotliwości oraz szumy uszne. W diagnostyce MD stosowane są różne badania, takie jak audiometria tonalna, elektrokochleografia, test glicerolowy, próba kaloryczna i badanie CHAMP (procedura badania wodniaka ślimaka z maskowaniem). Ostatnio zaczęto stosować badania miogennych przedsionkowych potencjałów wywołanych szyjnych i wzrokowych do pomiaru odpowiednio odruchu woreczkowo-szyjnego i otolitowo-okoruchowego. Celem niniejszej pracy jest przedstawienie przeglądu testów szyjnych i wzrokowych miogennych przedsionkowych potencjałów wywołanych u osób z MD.
\end{abstract}

Słowa kluczowe: choroba Meniere’a • szyjne miogenne przedsionkowe potencjały wywołane • wzrokowe miogenne przedsionkowe potencjały wywołane

\section{Background}

For the treatment of patients with vestibular system disorder, diagnostic evaluation of the vestibular system becomes an essential aspect. Vestibular system being a complex system, comprises of several anatomical structures. Testing methods such as caloric test mainly assesses the functioning of the horizontal semicircular canal and superior vestibular nerve, which is only a portion of the vestibular system. Recently the assessment of otolith functioning through Vestibular Evoked Myogenic Potential testing (VEMP) has emerged. VEMP responses are usually recorded by presenting loud acoustic stimulation. Two types of VEMP responses have been reported in the literature: Cervical vestibular evoked myogenic potentials (cVEMPs) and Ocular Vestibular evoked myogenic potentials (oVEMPs).

cVEMPs mainly assess the functioning of saccule and inferior vestibular nerve. The research evidence suggests that the pathway involved in cVEMPs are the saccule, inferior vestibular nerve, the medial vestibular nucleus, the medial vestibulospinal tract, and the motor neurons of the ipsilateral sternocleidomastoid muscle [1]. The typical cVEMPs waveform contains a positive peak which occurs at $13 \mathrm{msec}$ and a negative peak which occurs at $23 \mathrm{msec}$ (Figure 1).

Recently, ocular VEMP (oVEMPs) has become an important part of vestibular evaluation. oVEMPs was first demonstrated by Todd, Rosengren, and Colebatch [2]. Todd et al. [2]. They demonstrated that oVEMPs is a short latency vestibular evoked potential which has a negative peak at $10 \mathrm{~ms}$ (n10) and a positive peak at around $15 \mathrm{~ms}$ (p15). This response is obtained for a loud $500 \mathrm{~Hz}$ bone-conducted stimulus, which could be recorded by placing the electrode just below the eyes. The threshold of oVEMPs is similar to the cVEMPs thresholds and the oVEMPs are best recorded with the contralateral acoustic stimulation, from extraocular muscles slightly below the eyes [3]. The potential is myogenic in nature and is excitatory which arises from the vestibulo-ocular reflex [4] and not in response to the eye movement (Figure 2).

Cervical vestibular evoked myogenic potentials have been found useful in finding out the involvement of saccule or its end organ pathologies in various vestibular disorders such as: vestibular neuritis $[5,6]$, cerebellopontine angle tumor [7,8], auditory neuropathy [9-12]. Also, the cVEMPs has been found useful in the diagnosis of other vestibular pathologies such as Semicircular canal dehiscence syndrome [13], and multiple sclerosis [14].

Similarly, ocular vestibular evoked myogenic potentials (oVEMPs) also has been utilised in diagnosing internuclearophthalmoplegia[15], to differentiate between cerebellar and brainstem lesions [16] auditory neuropathy/audiovestibular neuropathy [9] superior semicircular canal dehiscence syndrome [17] and vestibular neuritis [18].

Meniere's disease is an inner ear disorder characterized by aural fullness, spontaneous attacks of vertigo, fluctuating low-frequency sensorineural hearing loss and tinnitus. Various tests such as puretone audiometry, Electrocochleography, Caloric test and Cochlear hydrops analysis masking have been utilised in diagnosing the Meniere's disease. The above mentioned tests do not give any information regarding the functioning of the otolith organs i.e the utricle and the saccule. cVEMPs give information about the functioning of the saccule, whereas, the oVEMPs give information about the utricle. The studies of cVEMPs and oVEMPs in Meniere's disease have been discussed in detail.

\section{Material and Methods}

Electronic searches were conducted in PubMed, Google, Google Scholar and in Scopus databases. The terminologies which were selected were: Vestibular evoked myogenic potentials, cervical Vestibular evoked myogenic potentials, ocular Vestibular evoked myogenic potentials, cervical Vestibular evoked myogenic potentials in Meniere's disease, ocular Vestibular evoked myogenic potentials in Meniere's disease, caloric test results in Meniere's disease, Vestibular test findings in individuals with Meniere's disease. The articles selected were then shortlisted according to the purpose of our study.

\section{Inclusion criteria}

We limited our search to articles published from 1999 to 2012. Articles written in English language were only considered for the study. 

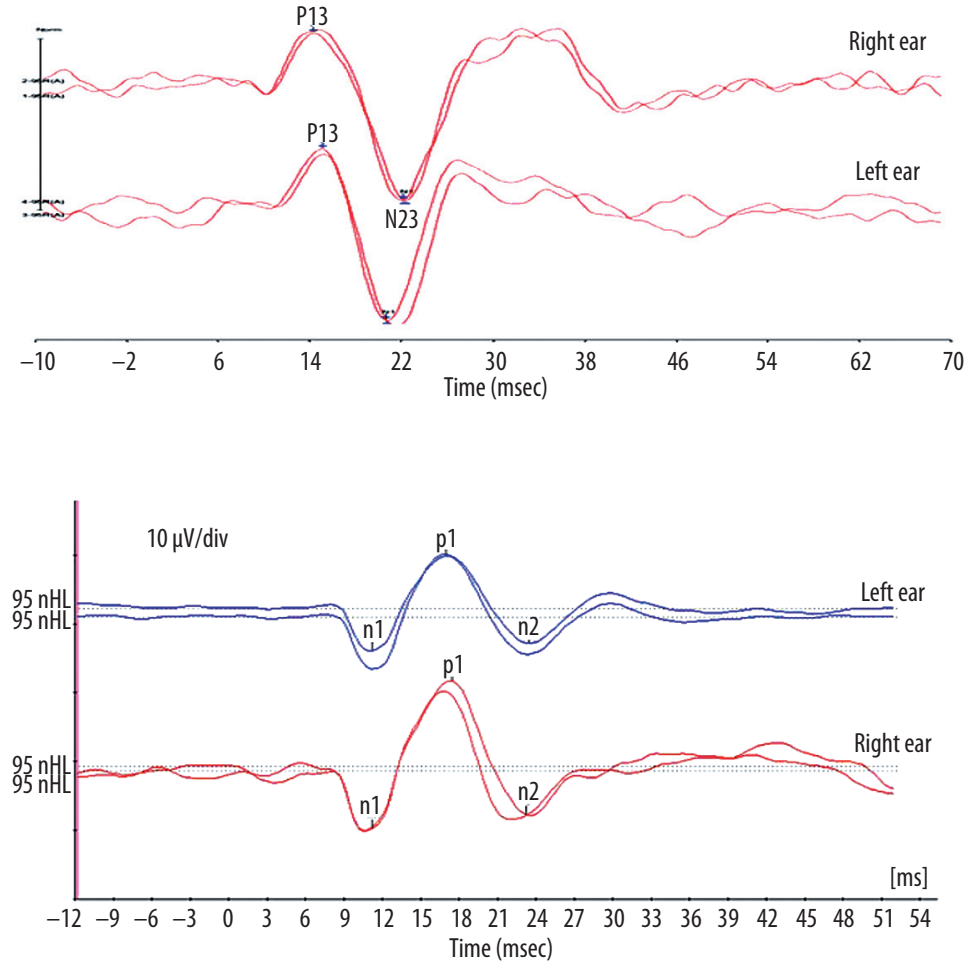

Figure 1. cVEMPs waveform from the right and left ear

Figure 2. oVEMPs response from a normal hearing person

\section{Exclusion criteria}

Articles other than Meniere's disease and other vestibular tests findings in Meniere's disease were excluded from the study. Finally, 28 articles were selected for the study.

\section{Results}

We discuss the results of the 28 articles from the database search and present our findings under three main headings: Cervical vestibular evoked myogenic potentials (cVEMPs) in Meniere's disease, Ocular vestibular evoked myogenic potentials (oVEMPs) in Minere's disease, Correlation between ENG, cVEMPs and oVEMPs.

Cervical vestibular evoked myogenic potentials (cVEMPs) in Meniere's disease

In individuals with Meniere's disease, variable incidence of abnormal cVEMPs has been reported. Murofushi, Matsuzaki and Shimizu [19] reported the incidence of abnormal VEMPs to be 39\% whereas, De Waele, Tran Ba Huy, Diard, Freyss and Vidal [20] reported 54\% of abnormal cVEMPs in individuals with Meniere's disease. Also, Murofushi and Kaga [21] reported the overall incidence of abnormal VEMPs in individuals with Meniere's disease to be 58\%. Akkuzu, Akkuzu and Ozluoglu [22] reported 50\% abnormal cVEMPs in individuals with Meniere's disease.

There are equivocal findings regarding latencies of cVEMPs in individuals with Meniere's disease. Chiarovano, Zamith, Vidal and Waele [23] reported latencies of cVEMPs on the affected side were not significantly different from the latencies on the intact side or those from the healthy subjects. However, latency of cVEMPs also has been found to be abnormal in asymptotic ears of individuals with Meniere's disease. Riberio, Almeida, Caovilla \& Ganaca [24] reported increased latency of cVEMPs in 35\% of the affected ears and in 25\% of the asymptomatic ears of individuals with Meniere's disease.

cVEMPs are either absent or decreased in amplitude on the affected side of the individuals with Meniere's disease. Murofushi, Shimizu, Takegoshi and Cheng [14] reviewed the records of click evoked cVEMPs in the individuals with Meniere's disease and compared it with the normal control group. They reported that 22 (51\%) out of 43 individuals showed abnormal amplitudes on the affected side.

The asymmetry in cVEMPs amplitude has also been reported in Meniere's disease. Hong, Yeo, Kim and Cha [25] found that $69 \%(\mathrm{~N}=26)$ of them showed abnormal cVEMPs and also reported that the cVEMPs amplitude asymmetry between the ears was more in this population. Authors concluded that the cVEMPs are most sensitive towards the testing of Meniere's disease.Young, Wu and Wu [26] reported increased interaural amplitude difference ratio in three subjects with Meniere's disease whereas, other seven subjects with Meniere's disease had steady cVEMPs. Authors concluded that the test results obtained from cVEMPs may serve as an indication of enlarged saccule, whose wall is in contact with the stapes footplate. Authors also concluded that cVEMPs testing may be useful in differentiating the initial stage and later stage of Meniere's disease.

There is a correlation between interaural amplitude difference ration and the stage of Meniere's disease. Young, Huang and Cheng [27] reported significant relationship between interaural amplitude difference ratio and the stage 
of Meniere's disease, but not for the percentage of unilateral weakness of caloric response and the stage of disease. Osei-Lah, Ceranic and Luxon [28] also reported that the interaural amplitude difference ratio differentiates the acute and stable stages of Meniere's disease.

Altered frequency tuning of cVEMPs responses is observed in Meniere's disease compared to the normal controls. Rauch, Zhou, Kujawa, Guinan and Herrmann [29] reported that normal subjects showed best response of cVEMPs (frequency tuning) at $500 \mathrm{~Hz}$ compared to the other frequencies $(250,1000,2000$, and $4000 \mathrm{~Hz})$. Compared to normal subjects, individuals with Meniere's disease showed less frequency tuning at $500 \mathrm{~Hz}$. Timmer et al. [30] studied the cVEMPs responses individuals with and without Tumarkin drop attacks. Unaffected ears of the subjects with unilateral Meniere's disease showed slightly altered tuning. Affected ears of the subjects with unilateral Meniere's disease showed significant altered tuning such as the $500 \mathrm{~Hz}$ threshold being equal to or higher than the $1000 \mathrm{~Hz}$ threshold. Node et al. [31] also reported that the peak amplitudes of cVEMPs are highest at $500 \mathrm{~Hz}$ in individuals with normal vestibular system whereas, the amplitude of cVEMPs was highest at $1,000 \mathrm{~Hz}$ in the subjects with Meniere's disease.

Another parameter of cVEMPs which has been evaluated is the threshold of the cVEMPs. cVEMPs threshold is found to be elevated in individuals with Meniere's disease. Rauch, Silveria, Zhou, Kujawa, Guinan and Herrmann [29] reported that, Meniere's ears had significantly increased cVEMPs thresholds. Unaffected ears of Meniere's subjects also showed significantly elevated cVEMPs thresholds compared with normal subjects. Authors concluded that in Meniere's disease, there is alteration in the saccular motion mechanics. Timmer et al. [30] measured cVEMPs thresholds in individuals with and without $\mathrm{Tu}-$ markin drop attacks. Affected ears of the subjects with unilateral Meniere's disease showed elevated thresholds. cVEMPs thresholds were greater at all frequencies for the affected Meniere's disease with drop attacks when compared to those without drop attacks.

High sensitivity has been reported for cVEMPs threshold in the side of disease in unilateral Meniere's disease. Rauch et al. [29] studied the usefulness of cVEMPs threshold and caloric asymmetry in the affected side of individuals with unilateral Meniere's disease. Results showed that cVEMPs threshold was shown to be highly sensitive to the affected side of individuals with unilateral Meniere's disease. There were instances of discordance in side of disease assignment by caloric asymmetry and cVEMPs methods but there was no condition where both methods were incorrect. The authors concluded that cVEMPs provide information which is different from those provided by other components of the vestibular assessment.

Also, CVEMPs is useful in assessing the functioning of saccule during the Meniere's disease attack. Otolith functioning was measured in the same patients both during an acute attack of Meniere's disease (MD) and in the quiescent period between attacks by Manzari, Tedesco, Burgess and Curthoys [32]. Results of the study revealed that, in response to $500 \mathrm{~Hz}$ bone conducted cVEMPs; there is a significant decrease in the amplitude of the p13 peak of the cVEMPs in the affected ear during the attack compared to quiescence.

When combined with glycerol the cVEMPs could give important information about the Meniere's disease. Murofushi, Matsuzaki and Takegoshi [33] reported a significant increase in the amplitude of the P13-N23 complex of cVEMPs in five subjects with Meniere's disease whereas, in the other two subjects a significant reduction in amplitude of the P13-N23 complex was noted after oral administration of glycerol. The increase or decrease in amplitude of the P13-N23 complex was reported to be independent of the pure tone threshold. Ban, Lee, Jin and Lee [34] also reported a significant increase in amplitude of the p1-n1 biphasic wave in $39.3 \%$ of the subjects, whereas a decrease in amplitude in $7.1 \%$ of the subjects with Meniere's disease after the administration of glycerol. They also reported no association between cVEMPs results and puretone threshold of individuals with Meniere's disease.

\section{Ocular Vestibular evoked myogenic potentials (oVEMPs) in Meniere's disease}

Normal latencies of oVEMPs responses are observed in individuals with Meniere's disease. Chiarovano, Zamith, Vidal and Waele [23] found that latencies of oVEMPs on the affected side were not significantly different from latencies on the intact side or those from the healthy subjects.

A lower response rate, smaller amplitude, and higher threshold of the oVEMPs indicate the pathologic disease in Meniere's subjects. Winters, Camoschroer, Grolman and Klis [35] reported that a lower response rate and decreased amplitude of oVEMPs in individuals with Meniere's disease. This effect was observed in patients with Meniere's disease in both the ears. The clinically unaffected ear was found to be less altered when compared to the affected ear.

With the use of altered tuning of oVEMPs for Meniere's disease subjects, the authors have tried to identify ear with Meniere's disease. Winters, Berq, Grolman and Klis [36] reported that in normal subjects, oVEMPs amplitude is greater and threshold is lower at $500 \mathrm{~Hz}$, whereas, in ears with Meniere's disease, lower amplitudes and elevated thresholds compared to normal subjects at 250, $500,1000 \mathrm{~Hz}$ were recorded in both the ear with Meniere's disease and the unaffected ear. Additionally, for ears with Meniere's disease were showed best tuning at $1000 \mathrm{~Hz}$.

Sandhu, Low, Rea and Saunders [37] also reported altered tuning of oVEMPs in individuals with Meniere's disease. oVEMPs was recorded in 8 individuals with normal auditory system (16 ears) and 12 individuals with unilateral Meniere's disease ( 8 with definite disease and 4 with probable disease). oVEMPs was recorded using tone bursts at 250, 500, 750, 1,000, 1,500, 2,000, 3,000, and 4,000 Hz. oVEMPs were present in all ears tested. In individuals with normal auditory system, at $500 \mathrm{~Hz}$ the oVEMPs amplitudes were larger whereas, in ears with Meniere's disease the frequency tuning shifted to higher side. The amount of shift was less in the probable Meniere's group and was absent in the unaffected ears. Based on the above findings, it can be concluded that, oVEMPs could be a useful tool to separate the Meinere's ear from non-Meniere's ears. 
Correlation between ENG, cVEMPs and oVEMPs in Meniere's disease

oVEMPs were more frequently absent than cVEMPs in individuals with Meniere's disease. Chiarovano et al. [23] reported that many subjects had abnormal results in oVEMPs than in cVEMPs. In $50 \%$ of subjects, there was dissociation between oVEMPs and cVEMPs. The degree of canal weakness in caloric testing was not correlated with either presence or absence of either oVEMPs or cVEMPs on the affected side.

In early stages of Meniere's disease, abnormal findings are first evident in cVEMPs than oVEMPs or caloric testing. Murofushi, Nakahara, Yoshimura and Tsuda [38] revealed that, the individuals with Meniere's disease did not show a significant association between their air conducted stimuli evoked oVEMPs and cVEMPs findings but there was an association of oVEMPs findings with caloric test findings. When the Meniere's disease patients were classified into four stages based on their hearing levels, the subjects showed abnormal findings at earlier stages on air conducted stimuli evoked cVEMPs than on the other tests.

There is no correlation between bone conduction evoked oVEMPs and cVEMPs or oVEMPs and caloric responses in individuals with Meniere's disease. Huang, Wang and Young [39] found that abnormal caloric, oVEMPs and cVEMPs test results were obtained for $24 \%$, $44 \%$, and $38 \%$ of hydropic ears respectively. No correlation existed between any two test results.

Patterns of abnormality in caloric testing, oVEMPs and cVEMPs may provide the location or locations of vestibular dysfunction in vestibular system. Jacobson et al. [40] reported that in a patient with unilateral Meniere's disease cVEMPs were absent on the affected side and present on the unaffected side. oVEMPs and caloric responses were bilaterally normal. oVEMPs and cVEMPs measure different part of the peripheral vestibular system, i.e., oVEMPs assesses the functioning of the utricle and also superior portion of the vestibular nerve whereas cVEMPs assesses the functioning of saccule. Iwasaki, Takai, Ito and Murofushi [41] reported abnormal VEMP responses with normal caloric test responses in 12 individuals diagnosed with Meniere's disease.

\section{Discussion and Conclusions}

The review had three aims: provide an overview of cervical vestibular evoked myogenic potentials results in individuals with Meniere's disease, provide an overview of the ocular vestibular evoked myogenic potentials results in individuals with Meniere's disease and also to provide an overview of correlation between cervical vestibular evoked myogenic potentials, ocular vestibular evoked myogenic potentials and caloric test results in individuals with Meniere's disease.

VEMPs have an important position in the vestibular evaluation test battery for assessment of individuals with various vestibular dysfunction. VEMPs is thought to reflect stimulation of the saccule and/or utricle, sensory structures not currently evaluated by traditional electronystagmographic methods. The neural pathways underlying VEMPs responses are different from semicircular canal ocular reflex pathway which is assessed traditionally by standard ENG test battery. So, inclusion of VEMPs in assessment of individuals with vestibular dysfunction may help us to better understand the pathological processes involved in the vestibular system.

Various parameters of both cVEMPs and oVEMPs in individuals with Meniere's disease have been evaluated. Various parameters which have been evaluated in individuals with Meniere's disease are latency, amplitude, interaural amplitude ratio, frequency tuning of the CVEMPs and oVEMPs. Both cervical and ocular vestibular evoked myogenic potentials are affected in individuals with Meniere's disease. Although there is variability in the results of the studies but overall all the studies report one or the other parameters of cVEMPs and oVEMPs are affected in individuals with Meniere's disease. The above studies also report that combining the three test results viz: cVEMPs, oVEMPs and caloric test results in individuals with Meniere's disease can provide topographical information about the site of lesion in individuals with Meniere's disease.

\section{Declaration of Interest}

The authors report no conflicts of interest. The authors alone are responsible for the content and writing of the paper.

\section{Acknowledgements}

The authors thank Director of AIISH for constant support and guidance. The authors also thank the HOD audiology for his constant guidance. The author's also thank the reviewer's of the manuscript for comments on the earlier version of this manuscript.

\section{References:}

1. Halmagyi GM, Curthoys IS. Clinical testing of otolith functions. Ann NY Acad Sci, 1999; 871: 195-204.

2. Todd NP, Rosengren SM, Aw ST, Colebatch JG. Ocular vestibular evoked myogenic potentials (OVEMPSs) produced by air- and bone-conducted sound. Clin Neurophysiol, 2003; 118: 381-90.

3. Rosengren SM, Todd NP, Colebatch JG. Vestibular-evoked extraocular potentials produced by stimulation with bone-conducted sound. Clin Neurophysiol, 2005; 116: 1938-48.
4. Chihara Y, Iwasaki S, Ushio M, Fujimoto C, Kashio A, Kondo K et al. Ocular vestibular-evoked myogenic potentials (oVEMPs) require extraocular muscles but not facial or cochlear nerve activity. Clin Neurophysiol, 2009; 120: 581-87.

5. Chihara Y, Iwasaki S, Murofushi T, Yagi M, Inoue A, Fujimoto $C$ et al. Clinical characteristics of inferior vestibular neuritis. Acta Otolaryngol, 2012; 132(12): 1288-94. 
6. Manzari L, Burgess AM, Curthoys IS. Ocular and cervical vestibular evoked myogenic potentials in response to bone-conducted vibration in patients with probable inferior vestibular neuritis. J Laryngol Otol, 2012; 126(7): 683-91.

7. Beyea JA, Zeitouni AG. Vestibular evoked myogenic potential latencies in Meniere's disease and vestibular schwannoma: J Otolaryngol Head Neck Surg, 2010; 39(3): 253-58.

8. Murofushi T, Takehisa M. Vestibular schwannoma with absent vestibular evoked myogenic potentials to clicks but normal ABR, caloric responses and vestibular evoked myogenic potentials to $500 \mathrm{~Hz}$ tone bursts. Acta Otolaryngol, 2010; 130(4): 525-28.

9. Sinha SK, Kruthika S, Saranya R. cVEMP and oVEMP test findings in Individuals with auditory neuropathy. Audiology Research, 2013; 3(e4): 26-30.

10. Kumar K, Singh NK, Sinha SK, Bharti A, Barman A. Vestibular evoked myogenic potentials as a tool to assess vestibulocolic pathway dysfunction in individuals with auditory neuropathy. Asia Pac J Speech Lang Hear, 2007; 10: 110-18.

11. Sinha SK, Barman A, Singh NK, Rajeshwari G, Sharanya R. Involvement of peripheral vestibular nerve in individuals with auditory neuropathy. Eur Arch Otorhinolaryngol, 2013; 270(8): 2207-14.

12. Sinha SK, Barman A, Singh NK, Rajeshwari G, Sharanya R. Vestibular test findings in individuals with auditory neuropathy: review. J Laryngol Otol, 2013; 127(5): 448-51.

13. Brantberg K, Verrecchia L. Effectiveness of different click stimuli in diagnosing superior canal dehiscence using cervical vestibular evoked myogenic potentials. Acta Otolaryngol, 2012; 132(10): 1077-83.

14. Murofushi T, Shimizu K, Takegoshi H, Cheng PW. Diagnostic value of prolonged latencies in the vestibular evoked myogenic potential. Arch Otolaryngol Head Neck Surg, 2001; 127: 1069-72.

15. Rosengren SM, Colebatch JG. Ocular vestibular evoked myogenic potentials are abnormal in internuclear ophthalmoplegia. Clin Neurophysiol, 2011; 122: 1264-67.

16. Su Chiang, Young YE. Differentiating cerebellar and brainstem lesions with ocular vestibular-evoked myogenic potential test. Eur Arch Otorhinolaryngol, 2011; 268: 923-30.

17. Rosengren SM, Aw ST, Halmagyi GM, Mc Angu S, Todd NP, Colebatch JG. Ocular vestibular evoked myogenic potentials in superior canal dehiscence. J Neuro Neurosur Psychiatr, 2008; 79: 559-68.

18. Murofushi T, Nakahara H, Yoshimura E, Tsuda Y. Association of air-conducted sound oVEMP findings with cVEMP and caloric test findings in patients with unilateral peripheral vestibular disorders. Acta Otolaryngol, 2011; 131(9): 945-50.

19. Murofushi T, Matsuzaki M, Shimizu K. Vestibular-evoked myogenic potentials in patients with unilateral Meniere's disease, 2008; In: Sterkers O, Ferrary E, Dauman R, et al. (eds.), Meniere's disease - update(pp. 353-58). Kugler: The Hague, 1999.

20. De Waele C, Tran Ba Huy P, Diard JP, Freyss G, Vidal PP: Saccular dysfunction in Meniere's disease. Am J Otol, 1999; 20: 223-32.

21. Murofushi T, Kaga K. Vestibular evoked myogenic potential: its basics and clinical application. Tokyo: Springer, 2009.

22. Akkuzu G, Akkuzu B, OzluogluLN: Vestibular evoked myogenic potentials in benign paroxysmal positional vertigo and Meniere's disease. Eur Arch Otorhinolaryngol, 2006; 263: 510-17.
23. Chiarovano E, Zamith F, Vidal PP, De Waele C. Ocular and cervical VEMPs: a study of 74 patients suffering from peripheral vestibular disorders: Clin Neurophysiol, 2011; 122: 1650-59

24. Ribeiro S, Almeida RR, Caovilla HH, Gananca MM. Vestibular evoked myogenic potentials in affected and asymptomatic ears in unilateral Meniere's disease. Braz J Otorhinolaryngol, 2005; 71(1): 60-66.

25. Hong SM, Yeo S, Kim C, Cha T. The results of vestibular evoked myogenic potentials, with consideration of age-related changes, in vestibular neuritis, benign paroxysmal positional vertigo, and Meniere's disease. Acta Otolaryngol, 2008; 128: 861-65.

26. Young $\mathrm{YH}, \mathrm{Wu} \mathrm{CC}, \mathrm{Wu} \mathrm{CH}$. Augmentation of vestibular evoked myogenic potentials: an indication for distended saccular hydrops. Laryngoscope, 2002; 112(3): 509-12.

27. Young YH, Huang TW, Cheng PW. Assessing the stage of Meniere's disease using vestibular evoked myogenic potentials. Arch Otolaryngol Head Neck Surg, 2003; 129: 815-18.

28. Osei-Lah V, Ceranic B, Luxon LM. Clinical value of tone burst vestibular evoked myogenic potentials at threshold in acute and stable Meniere's disease. J Laryngol Otol, 2008; 122: 452-57.

29. RauchSD, Silveira MB, Zhou G, Kujawa SG, Guinan JJ, Herrmann BS. Vestibular evoked myogenic potentials versus vestibular test battery in patients with Meniere's disease. Otol Neurotol, 2004; 25: 981-86.

30. Timmer FC, Zhou G, Guinan JJ, Kujawa SG, Herrman BS, Rauch SD. Vestibular evoked myogenic potential (VEMPS) in patients with Meniere's disease with drop attacks. Laryngoscope, 2006; 116: 776-79.

31. Node M, Miyamoto A, Adachi A, Hashimoto M, Sakagami M. Frequency dynamics shift of vestibular evoked myogenic potentials in patients with endolymphatic hydrops. Otol Neurotol, 2005; 26: 1208-13.

32. Manzari L, Tedesco AR, Burgess AM, Curthoys IS. Ocular and cervical vestibular-evoked myogenic potentials to bone conducted vibration in Meniere's disease during quiescence $v s$ during acute attacks. Clin Neurophysiol, 2010; 121(7): 1092-101

33. Murofushi T, Matsuzaki M, Tagekoshi H. Glycerol affects vestibular evoked myogenic potentials in Meniere's disease. Auris Nasus Larynx, 2001; 28: 205-8.

34. Ban JH, Lee JK, Jin SM, Lee KC: Glycerol pure tone audiometry and glycerol vestibular evoked myogenic potential: representing specific status of endolymphatic hydrops in the inner ear. Eur Arch Otorhinolaryngol, 2007; 264: 1276-81.

35. Winters SM, Campschroer T, Grolman W, Klis SF. Ocular vestibular evoked myogenic potentials in response to air-conducted sound in Meniere's disease. Otol Neurotol, 2011; 32(8): 1273-80.

36. Winters SM, Berg IT, Grolman W, Klis SF. Ocular vestibular evoked myogenic potentials: frequency tuning to air-conducted acoustic stimuli in healthy subjects and Meniere's disease. Audiol Neurotol, 2012; 17: 12-19.

37. Sandhu JS, Low R, Rea PA, Saunders NC: Altered frequency dynamics of cervical and ocular vestibular evoked myogenic potentials in patients with Meniere's disease. Otol Neurotol, 2012; 33(3): 444-49.

38. Murofushi T, Nakahara H, Yoshimura E, Tsuda Y. Association of air-conducted sound oVEMPs findings with cVEMPs and caloric test findings in patient with unilateral peripheral vestibular disorders. Acta Otolaryngol, 2011; 131: 945-50.

39. Huang $\mathrm{CH}$, Wang SJ, Young YH. Correlation between caloric and ocular vestibular evoked myogenic potential test results. Acta Otolaryngol, 2012; 132: 160-66. 
40. Jacobson GP, McCaslin DL, Piker EG, Gruenwald J, Grantham SL, Tegel L. Patterns of Abnormality in cVEMPs, oVEMPs, and Caloric tests may provide topological information about vestibular impairment. J Am Acad Audiol, 2011; 22: 601-11.
41. Iwasaki S, Takai Y, Ito K, Murofushi T. Abnormal vestibular evoked myogenic potentials in the presence of normal caloric responses. Otol Neurotol, 2005; 26: 1196-99. 